\title{
Autologous stem cell transplantation for refractory juvenile idiopathic arthritis: analysis of clinical effects, mortality, and transplant related morbidity
}

\author{
I M de Kleer, D M C Brinkman, A Ferster, M Abinun, P Quartier, J van der Net, R ten Cate, \\ L R Wedderburn, G Horneff, J Oppermann, F Zintl, H E Foster, A M Prieur, A Fasth, \\ $M$ A J van Rossum, W Kuis, N M Wulffraat
}

See end of article for authors' affiliations

\section{Correspondence to:} Dr N M Wulffraat, Paediatric BMT unit, Suite KC 03.063, University Medical Centre Utrecht, PO box 85090,3508 AB Utrecht, Netherlands: n.wulffraat@wkz.azu.nl

Accepted

6 November 2003

\begin{abstract}
Objective: To evaluate the safety and efficacy of autologous stem cell transplantation (ASCT) for refractory juvenile idiopathic arthritis (JIA).

Design: Retrospective analysis of follow up data on 34 children with JIA who were treated with ASCT in nine different European transplant centres. Rheumatological evaluation employed a modified set of core criteria. Immunological reconstitution and infectious complications were monitored at three month intervals after transplantation.

Results: Clinical follow up ranged from 12 to 60 months. Eighteen of the 34 patients (53\%) with a follow up of 12 to 60 months achieved complete drug-free remission. Seven of these patients had previously failed treatment with anti-TNF. Six of the 34 patients (18\%) showed a partial response (ranging from $30 \%$ to $70 \%$ improvement) and seven (21\%) were resistant to ASCT. Infectious complications were common. There were three cases of transplant related mortality (9\%) and two of disease related mortality (6\%).

Conclusions: ASCT in severely ill patients with JIA induces a drug-free remission of the disease and a profound increase in general wellbeing in a substantial proportion of patients, but the procedure carries a significant mortality risk. The following adjustments are proposed for future protocols: (1) elimination of total body irradiation from the conditioning regimen; (2) prophylactic administration of antiviral drugs and intravenous immunoglobulins until there is a normal CD4+ T cell count.
\end{abstract}

J uvenile idiopathic arthritis (JIA) is the most common rheumatic disease in childhood and a major cause of disability. Although the overall prognosis for most children with chronic arthritis is good, in $5-10 \%$ of children with the systemic and polyarticular onset forms, the disease is refractory to conventional treatment, which comprises combinations of non-steroidal anti-inflammatory drugs (NSAID) and immunosuppressive drugs such as methotrexate and corticosteroids. ${ }^{1-5}$ In such cases, there is considerable morbidity from severe joint destruction, growth retardation, psychosocial morbidity, and various adverse effects from long term treatment with immunosuppressive drugs. Mortality in the whole group of systemic onset children is estimated to be $2-4 \%{ }^{6}$ The major causes of mortality relate to drug toxicity, intercurrent infection, amyloidosis, ${ }^{7}$ and the evolution of disease to conditions overlapping with other rheumatic diseases, such as systemic lupus erythematosus or scleroderma. ${ }^{8}$

Recently, the introduction of anti-tumour necrosis factor (TNF) therapy appeared to have a major impact on outcome of children with polyarticular JIA who were unresponsive to methotrexate, with a persistent response in up to $80 \%{ }^{9}$ However, in active systemic onset JIA this treatment seems less effective. ${ }^{10-12}$ Another new treatment approach for patients with severe autoimmune disease involves intense immunosuppression followed by autologous haematopoietic stem cell transplantation (ASCT). ${ }^{13-17}$ The rationale of this treatment is based on the concept of intense immunosuppression, with subsequent regeneration of naïve $\mathrm{T}$ lymphocytes derived from reinfused haematopoietic progenitor cells. The European League Against Rheumatism (EULAR) and the European Group for Blood and Marrow Transplantation (EBMT) have published guidelines on inclusion criteria, the conditioning regimen, and manipulation of the graft. ${ }^{18}{ }^{19}$ Since 1997, ASCT has been applied as an experimental procedure in a substantial group of children with refractory polyarticular and systemic JIA. ${ }^{20-23}$ The majority of these patients $(n=41)$ can be identified in the registry of the EBMT. Recently we published a short report on the general outcome of 31 of these children. ${ }^{24}$ The reported mortality of ASCT in JIA is a major concern.

We report here a more detailed survey of the follow up of 34 of the registered JIA patients who were treated with ASCT in nine different European centres. We evaluate the safety and efficacy of ASCT in this severely ill patient group, with specific attention to infectious complications and transplant related mortality. New adjustments in the transplantation protocol are proposed.

\section{METHODS}

\section{Patient selection}

We present data on 34 of the 41 JIA patients who received ASCT, identified in the EBMT registry. The patients received their transplants in nine different paediatric transplantation centres in Europe (table 1). For seven patients registered at the EBMT, the data were not detailed enough to allow follow up evaluation.

Abbreviations: ASCT, autologous stem cell transplantation; ATG, antithymocyte immunoglobulin; $\mathrm{CHAQ}$, child health assessment questionnaire; DMARD, disease modifying anti-rheumatic drug; EBMT, European Group for Blood and Marrow Transplantation; IAHS, infection associated haemophagocytic syndrome; JIA, juvenile idiopathic arthritis; NSAID, non-steroidal anti-inflammatory drug; TBI, total body irradiation; TNF, tumour necrosis factor; VAS, visual analogue scale 
Table 1 Clinical characteristics before autologous stem cell transplantation

\begin{tabular}{|c|c|c|c|c|c|c|c|c|}
\hline Case & $\mathrm{CP}$ & Sex & Type & Onset & Drug treatment history & Toxicity from antirheumatic drugs & ASCT & FU \\
\hline 1 & A & $\mathrm{F}$ & Syst & $11 \mathrm{~m}$ & st, MTX, NSAID, CsA, aza, IVIG & GD, O & $6 y, 7 \mathrm{~m}$ & $5 y$ \\
\hline 2 & $A$ & M & Syst & $4 y, 7 \mathrm{~m}$ & $\begin{array}{l}\text { st, MTX, NSAID, CsA, sulpha, } \\
\text { aza, Plaq, cy }\end{array}$ & $G D, O$ & $10 y, 6 \mathrm{~m}$ & $4 y$ \\
\hline 3 & $A$ & M & Syst & $2 y, 6 m$ & st, MTX, CsA, NSAID & GD, O & $11 \mathrm{y}, 5 \mathrm{~m}$ & $4 y, 6 \mathrm{~m}$ \\
\hline 4 & A & M & Syst & $1 \mathrm{y}, 2 \mathrm{~m}$ & $\begin{array}{l}\text { st, MTX, CsA, NSAID, cy, } \\
\text { anti-TNF } \alpha\end{array}$ & $\begin{array}{l}\mathrm{GD}, \mathrm{O} \text {, vertebral fractures, } \\
\text { hypertension, hypertonia }\end{array}$ & $4 y, 11 \mathrm{~m}$ & + \\
\hline 5 & A & M & Syst & $4 y, 10 \mathrm{~m}$ & $\begin{array}{l}\text { st, MTX, CsA, NSAID, aza, } \\
\text { IVIG }\end{array}$ & GD, O & $9 y, 5 \mathrm{~m}$ & $3 y, 6 \mathrm{~m}$ \\
\hline 6 & A & M & Poly & $1 \mathrm{y}, 6 \mathrm{~m}$ & $\begin{array}{l}\text { st, MTX, CsA, sulpha, gold im, } \\
\text { hydroxy }\end{array}$ & $\begin{array}{l}\mathrm{GD}, \mathrm{O} \text {, severe Cushing, } \\
\text { hypertensive convulsions, } \\
\text { proteinuria }\end{array}$ & $9 y, 3 \mathrm{~m}$ & $3 y$ \\
\hline 7 & A & $\mathrm{F}$ & Syst & $5 y, 2 \mathrm{~m}$ & $\begin{array}{l}\text { st, MTX, CsA, NSAID, sulpha, } \\
\text { aza, IVIG }\end{array}$ & $\mathrm{GD}, \mathrm{O}$ & $11 \mathrm{y}, 3 \mathrm{~m}$ & $4 y$ \\
\hline 8 & A & $\mathrm{F}$ & Syst & $3 y, 8 m$ & $\begin{array}{l}\text { st, MTX, CsA, NSAID, aza, } \\
\text { hydroxy }\end{array}$ & $\begin{array}{l}\mathrm{GD}, \mathrm{O} \text {, severe relapsing } \\
\text { pneumonitis }\end{array}$ & $14 \mathrm{y}, 11 \mathrm{~m}$ & $\dagger$ \\
\hline 9 & A & $\mathrm{F}$ & Poly & $3 y, 11 \mathrm{~m}$ & st, MTX, CsA, NSAID. & $G D, O$ & $7 y, 10 m$ & $5 y$ \\
\hline 10 & A & $\mathrm{F}$ & Syst & $7 \mathrm{y}, 7 \mathrm{~m}$ & st, MTX, CsA, NSAID & $\mathrm{GD}, \mathrm{O}$, liver failure & $10 y, 7 \mathrm{~m}$ & $2 y, 6 \mathrm{~m}$ \\
\hline 11 & A & M & Syst & $1 \mathrm{y}, 8 \mathrm{~m}$ & st, MTX, CsA, NSAID, anti-TNF $\alpha$ & GD, O & $5 y, 2 \mathrm{~m}$ & $1 y$ \\
\hline 12 & A & M & Poly & $2 y, 2 m$ & st, MTX, CsA, NSAID, sulpha & $\mathrm{GD}, \mathrm{O}$, severe $\mathrm{GI}$ toxicity & $8 y, 5 m$ & $2 y$ \\
\hline 13 & A & M & Syst & $4 y, 1 \mathrm{~m}$ & $\begin{array}{l}\text { st, MTX, NSAID, sulpha, } \\
\text { Aureo, aza }\end{array}$ & $G D, O$, severe myelosuppression & $13 y, 10 \mathrm{~m}$ & $4 y, 6 \mathrm{~m}$ \\
\hline 14 & A & $\mathrm{F}$ & Syst & $3 y, 1 \mathrm{~m}$ & st, MTX, CsA, NSAID & GD, O & $5 y, 5 \mathrm{~m}$ & $2 y$ \\
\hline 15 & $A$ & $M$ & Syst & $3 y, 2 m$ & st, MTX, CsA, NSAID & GD, O, Cushing & $4 y, 3 \mathrm{~m}$ & $t$ \\
\hline 16 & A & M & Syst & $5 y, 5 \mathrm{~m}$ & st, MTX, CsA, NSAID, anti-TNF $\alpha$ & $G D, O$, severe $G$ l toxicity & $7 y, 9 m$ & $1 \mathrm{y}, 6 \mathrm{~m}$ \\
\hline 17 & A & M & Syst & $2 y, 10 m$ & st, MTX, CsA, NSAID, anti-TNF $\alpha$ & $\mathrm{GD}, \mathrm{O}$ & $11 \mathrm{y}, 7 \mathrm{~m}$ & $1 y$ \\
\hline 18 & A & M & Syst & $1 \mathrm{y}, 6 \mathrm{~m}$ & st, CsA, MTX, NSAID & $\mathrm{GD}, \mathrm{O}$, hypertension & $8 y, 2 m$ & $1 \mathrm{y}, 6 \mathrm{~m}$ \\
\hline 19 & $A$ & M & Poly & $3 y, 1 \mathrm{~m}$ & st, MTX, NSAID, sala & $\mathrm{GD}, \mathrm{O}$ & $5 y, 8 \mathrm{~m}$ & $4 y$ \\
\hline 20 & A & M & Syst & $8 y, 11 \mathrm{~m}$ & $\begin{array}{l}\text { st, MTX, CsA, NSAID, } \\
\text { cy, anti-TNF } \alpha \text {, IVIG }\end{array}$ & GD, severe myelosuppression & $12 \mathrm{y}, 4 \mathrm{~m}$ & $1 y$ \\
\hline 21 & B & $\mathrm{F}$ & Syst & $2 y, 11 \mathrm{~m}$ & st, MTX, NSAID, IVIG & $\begin{array}{l}\text { GD, cataracts, avascular } \\
\text { necrosis of femoral head }\end{array}$ & $11 \mathrm{y}, 1 \mathrm{~m}$ & $2 y, 6 \mathrm{~m}$ \\
\hline 22 & B & M & Syst & $8 m$ & st, MTX, CsA, NSAID & $\begin{array}{l}\text { Growth delay, cataracts, } \\
\text { avascular necrosis of femoral } \\
\text { head }\end{array}$ & $8 y, 9 m$ & $2 y$ \\
\hline 23 & B & $\mathrm{F}$ & Syst & $4 y, 3 \mathrm{~m}$ & $\begin{array}{l}\text { st, MTX, CsA, NSAID, cy, } \\
\text { IVIG }\end{array}$ & $\begin{array}{l}\text { GD, Cushing, GI haemorrhage, } \\
\text { avascular necrosis of femoral } \\
\text { head }\end{array}$ & $17 y$ & $3 y, 6 m$ \\
\hline 24 & C & $\mathrm{F}$ & Syst & $2 y, 9 m$ & $\begin{array}{l}\text { st, MTX, CsA, NSAID, cy, } \\
\text { chlor, IVIG, anti-TNF- } \alpha\end{array}$ & GD, severe hypertension & $5 y$ & $2 y$ \\
\hline 25 & C & $\mathrm{F}$ & Syst & $9 y, 2 m$ & $\begin{array}{l}\text { st, MTX, CsA, NSAID, cy, } \\
\text { chlor, IVIG, anti-TNF } \alpha\end{array}$ & $G D$, severe $\mathrm{Gl}$ toxicity & $14 y, 9 m$ & $2 y$ \\
\hline 26 & C & $\mathrm{F}$ & Syst & $2 y, 8 m$ & $\begin{array}{l}\text { st, MTX, CsA, NSAID, chlor, } \\
\text { IVIG, anti-TNF } \alpha\end{array}$ & $\begin{array}{l}\text { GD, severe myelosuppression, } \\
\text { hypertension, photosensitivity }\end{array}$ & $9 y, 9 \mathrm{~m}$ & $1 y$ \\
\hline 27 & B & M & Syst & $10 \mathrm{~m}$ & $\begin{array}{l}\text { st, MTX, CsA, NSAID, cy, } \\
\text { anti-TNF } \alpha\end{array}$ & $\begin{array}{l}\mathrm{GD}, \mathrm{O} \text {, vertebral compression } \\
\text { fracture }\end{array}$ & $5 y, 6 \mathrm{~m}$ & $1 \mathrm{y}, 6 \mathrm{~m}$ \\
\hline 28 & B & M & Syst & $8 y, 4 m$ & st, MTX, CsA, NSAID & $\begin{array}{l}\mathrm{GD}, \mathrm{O} \text {, avascular necrosis } \\
\text { femoral head, vertebral } \\
\text { compression fracture }\end{array}$ & $11 y$ & $1 y$ \\
\hline 29 & B & $\mathrm{F}$ & Syst & $7 y, 1 \mathrm{~m}$ & st, MTX, CsA, NSAID & $\begin{array}{l}\mathrm{GD}, \mathrm{O} \text {, intestinal perforation, } \\
\text { vertebral compression fracture }\end{array}$ & $9 \mathrm{y}, 1 \mathrm{~m}$ & $\dagger$ \\
\hline 30 & A & $\mathrm{F}$ & Syst & $2 y, 1 \mathrm{~m}$ & st, MTX, CsA, NSAID & GD, $O$, compression fractures & $4 y, 10 m$ & $2 y, 6 \mathrm{~m}$ \\
\hline 31 & A & $\mathrm{F}$ & Syst & $2 y, 7 m$ & st, MTX, CsA, NSAID, anti-TNF $\alpha$ & GD, O & $8 y, 5 m$ & \\
\hline 32 & $A$ & M & Syst & $10 y, 2 \mathrm{~m}$ & st, MTX, CsA, NSAID, cy, IVIG & $G D, O$, hepatic dysfunction & $18 y, 3 \mathrm{~m}$ & $3 y$ \\
\hline 33 & A & $\mathrm{F}$ & Syst & $4 y, 8 \mathrm{~m}$ & st, CsA, MTX, NSAID & $\mathrm{GD}, \mathrm{O}$, severe hypertension & $6 y, 9 \mathrm{~m}$ & $1 \mathrm{y}, 6 \mathrm{~m}$ \\
\hline 34 & B & M & Poly & $3 y, 3 m$ & st, MTX, NSAID, IVIG & $\begin{array}{l}\mathrm{GD}, \mathrm{O} \text {, vertebral fractures, } \\
\text { cataracts }\end{array}$ & $9 y, 11 \mathrm{~m}$ & $1 \mathrm{y}, 6 \mathrm{~m}$ \\
\hline Total & & $\begin{array}{l}19 / 15 \\
(\mathrm{M} / \mathrm{F})\end{array}$ & $29 / 5 \ddagger$ & $3 y, 11 \mathrm{~m}$ & & & $9 y, 5 \mathrm{~m}$ & $2 y, 4 \mathrm{~m}$ \\
\hline
\end{tabular}

anti-TNF $\alpha$, anti-tumour necrosis factor $\alpha$ receptor therapy; ASCT, autologous stem cell transplantation; Aureo, Aureomycin; aza, azathioprine; chlor, chlorambucil; CP, conditioning protocol; CsA, cyclosporin A; cy, cyclophosphamide; F, female; FU, follow up (years and months); GD, growth delay; hydroxy, hydroxychloroquine; IVIG, intravenous immunoglobulins; $m$, months; $M$, male; MTX, methotrexate; NSAID, non-steroidal anti-inflammatory drug; O, osteoporosis; Plaq, Plaquenil; poly, polyarticular; st, steroids; sulpha, sulphasalazine; syst, systemic; $y$, years.

†Death.

†n systemic/n polyarticular.

\section{Assessment of efficacy}

For rheumatological follow up we used the core set criteria described by Giannini and adopted by the Paediatric Rheumatology International Trials Organisation group (PRINTO). ${ }^{25-29}$ The core set consists of:

- physician's global assessment of overall wellbeing (visual analogue scale, VAS);

- parent/patient's assessment of pain (VAS);

- functional disability (child health assessment questionnaire, CHAQ);
- number of joints with active arthritis;

- number of joints with limited range of motion (paediatric EPM-ROM scale);

- erythrocyte sedimentation rate (ESR)..$^{27-29}$

The evolution of the disease in the patients was analysed by collecting the outcome of the core set of variables as recorded before stem cell collection and at three months intervals after transplantation.

Owing to the retrospective nature of this study, not all core set criteria were available from every time point for every 
child; thus Giannini's criteria for improvement were adapted. To meet the definition of improvement at a certain time point, patients had to have a persistent $30 \%$ or more improvement from baseline in at least three of the available variables (instead of three of six variables according to Giannini). Partial responders were thus defined as patients with a persistent $30 \%, 50 \%$, or $70 \%$ improvement from baseline in at least three response variables. They could also have worsening of $30 \%$ in no more than one of the available variables (instead of no more than one of six variables according to Giannini).

As no criteria for complete clinical remission in JIA have been defined, the American College of Rheumatology (ACR) criteria for complete remission in rheumatoid arthritis were used.$^{30}$ Full responders were defined as patients in complete drug-free remission, fulfilling at least 5 or more of the following requirements for the last two consecutive months: morning stiffness for less than 30 minutes, no fatigue, no joint pain, no joint tenderness or pain on motion, no soft tissue swelling in joints or tendon sheaths, and ESR $<20 \mathrm{~mm} / \mathrm{h}$.

A relapse was defined as a persistent worsening of $30 \%$ or more in three of the available core set criteria variables and a minimum of two active joints. There could also be improvement of $30 \%$ or more in no more than one of the six response variables. Flare up of disease was defined as a transient worsening of $30 \%$ or more in three of the available core set criteria variables and a minimum of two active joints.

\section{Statistical methods}

Treatment efficacy was evaluated by testing whether there was a difference in the core set criteria scores between baseline and the three monthly evaluations after transplantation, using the Wilcoxon signed-rank test. The effectiveness of total body irradiation (TBI) was evaluated by comparison of core set criteria scores between patients treated with TBI and those treated without TBI, using a Mann-Whitney U test. In order to evaluate the extent and duration of immunosuppression, the Wilcoxon signed-rank test was used to assess whether there were significant differences between baseline and the three monthly measurements of laboratory variables. To test whether there was a difference in $\mathrm{T}$ cell recovery between patients with a complete response and those with no or partial response, or between patients treated with different conditioning regimens, a Mann-Whitney U test was used. Correlations were calculated by linear regression.

\section{RESULTS}

\section{Clinical characteristics before ASCT}

The clinical characteristics before ASCT in all children were a polyarticular course complicated by erosions, osteoporosis, and stunted growth (table 1). In addition, all children with systemic JIA suffered periods of spiking fever, exanthemata, and severe corticosteroid related side effects. Ten of the 34 children had failed treatment with anti-TNF therapy. The mean time interval between diagnosis and transplant was 5 years, 4 months (SEM, 6 months). More details are shown in table 1 .

\section{Inclusion and exclusion criteria for ASCT}

In order to be eligible for ASCT, each centre used the agreed inclusion and exclusion criteria. ${ }^{18} 19$ The inclusion criteria were failure to respond to high dose methotrexate given by the intramuscular or subcutaneous routes $(1 \mathrm{mg} / \mathrm{kg} /$ week or $15 \mathrm{mg} / \mathrm{m}^{2}$ ), in addition to failure to respond to at least one other disease modifying anti-rheumatic drug (DMARD), corticosteroid dependency, or unacceptable toxicity from DMARDs or corticosteroids. After anti-TNF treatment became available, failure to respond to these agents was added to the inclusion criteria. Exclusion criteria were cardiorespiratory insufficiency, chronic active infection, persistent fever, and other signs of systemic disease activity despite corticosteroids at the time of assessment for transplant, end stage disease (Steinbrocker IV), or poor compliance.

\section{Bone marrow harvest and $\mathrm{T}$ cell depletion}

In 25 patients, bone marrow was harvested at least one month before ASCT. In nine patients autologous haematopoietic stem cells were mobilised into the peripheral blood using a single infusion of cyclophosphamide at $1.5-3.0 \mathrm{~g} / \mathrm{m}^{2}$ and granulocyte colony stimulating factor (G-CSF) at $10 \mu \mathrm{g} /$ $\mathrm{kg} / \mathrm{d}$. The graft was either purged by T cell depletion with CD2 and $\mathrm{CD} 3$ antibodies or by positive stem cell selection using CD34 selection devices. In the nine cases of peripheral bone marrow collection these techniques yielded a final suspension with a CD34+ cell count of $2.9-10.9 \times 10^{6}$ cells $/ \mathrm{kg}$ (mean $5.2 \times 10^{6}$ cells $\left./ \mathrm{kg}\right)$ and with a CD3+ cell count of $0-1.4 \times 10^{5}$ cells $/ \mathrm{kg}$ (mean $0.3 \times 10^{5}$ cells $/ \mathrm{kg}$ ). In the 25 cases of bone marrow collection these techniques yielded a final suspension with a CD34+ cell count of $0.44-6.0 \times 10^{6}$ cells $/ \mathrm{kg}$ (mean $2.2 \times 10^{6}$ cells $\left./ \mathrm{kg}\right)$ and with a CD3+ cell count of $0-3.5 \times 10^{5}$ cells $/ \mathrm{kg}$ (mean $0.7 \times 10^{5}$ cells $/ \mathrm{kg}$ ). The cell suspensions were frozen and stored until reinfusion. ${ }^{31}$

\section{Conditioning for ASCT}

In all, three different conditioning regimens were used (table 2). Conditioning regimen A (23 patients) included four days of anti-thymocyte rabbit immunoglobulin (ATG, SangStat, Fremont, California, USA), $5 \mathrm{mg} / \mathrm{kg}$ from day -9 to day -6 , cyclophosphamide $50 \mathrm{mg} / \mathrm{kg} /$ day from day -5 to day -2 , and low dose TBI (4 Gy, single fraction) on day -1 . Conditioning regimen $\mathrm{B}$ (eight patients) included the above scheme without TBI. Conditioning regimen $\mathrm{C}$ (three patients) included fludarabine $\left(30 \mathrm{mg} / \mathrm{m}^{2}\right)$ on day -7 and day -6 , cyclophosphamide $(50 \mathrm{mg} / \mathrm{kg} /$ day) from day -5 to day -2 , ATG $(5 \mathrm{mg} / \mathrm{kg})$ from day -6 to day -3 , methylprednisolone $\left(1 \mathrm{~g} / \mathrm{m}^{2}\right)$ from day -4 to day -2 , and no TBI. In all 34 children the frozen stem cell suspension was thawed and infused at day 0. Methotrexate and cyclosporin A were stopped before ASCT and prednisone was tapered when possible, starting not earlier than two months after ASCT. Disease flare up or relapse was treated in the same way as before ASCT.

\section{Engraftment and immunological reconstitution}

Engraftment occurred in all 34 patients with full haematological recovery. Detailed immunological reconstitution data were available for 29 patients (85\%). In these 29 patients neutrophil recovery $\left(>0.5 \times 10^{9} / \mathrm{l}\right)$ occurred between day 8 and day 30 post-ASCT (mean (SEM), 16 (1.1) days). Details of $\mathrm{T}$ cell recovery are given in fig $1 .^{32}$ All children suffered prolonged depression of CD4+ T cells, a common immunological feature also seen after intense chemotherapy. ${ }^{33} 34$ Twelve months after ASCT (range 6 to 18 months), the numbers of $\mathrm{CD} 4+\mathrm{T}$ cells were normal compared with baseline (Wilcoxon signed-rank test). A relatively fast reconstitution of CD8+ T cells resulted in an inverted $\mathrm{CD} 4+$ / CD8+ T cell ratio in 24 of 29 patients (83\%) lasting 3 to 18 months (mean (SEM), 9.2 (1.1) months). An early predominance of CD45RO+ memory cells was followed by the reappearance of CD45RA+ naive cells after six to nine months (fig 1). Three to 18 months after ASCT (mean 10.5 (1.6) months), in vitro mitogenic responses were normal. No differences were seen in T cell recovery between patients with a complete response and patients with no or partial response, or between patients treated with different regimens. 
Table 2 Clinical improvement after autologous stem cell transplantation at maximal follow up

\begin{tabular}{|c|c|c|c|c|c|c|c|c|}
\hline \multirow[b]{2}{*}{ Centre } & \multirow[b]{2}{*}{ Protocol } & \multirow{2}{*}{$\begin{array}{l}\text { Complete } \\
\text { remission }\end{array}$} & \multicolumn{3}{|c|}{ Partial response } & \multirow[b]{2}{*}{ No response } & \multirow[b]{2}{*}{ TRM } & \multirow[b]{2}{*}{ Total } \\
\hline & & & $30 \%$ & $50 \%$ & $70 \%$ & & & \\
\hline Utrecht† & $A$ & 5 & - & 3 & 1 & $2^{*}$ & 1 & 12 \\
\hline Leiden $\neq$ & $A$ & 3 & 1 & - & - & 2 & 1 & 7 \\
\hline London§ & $A$ & 1 & - & - & - & - & - & 1 \\
\hline Gothenburg & A & 1 & 1 & - & - & $1^{*}$ & - & 3 \\
\hline Brussels†† & B & 3 & - & - & - & - & - & 3 \\
\hline Halle-Wittenbergł‡ & B & 1 & - & - & - & - & - & 1 \\
\hline Paris§§ & B & 1 & - & - & - & 1 & 1 & 3 \\
\hline Newcastle & B & 1 & - & - & - & - & - & 1 \\
\hline Jena††† & C & 2 & - & - & - & 1 & - & 3 \\
\hline Total & & 18 & 2 & 3 & 1 & 7 & 3 & 34 \\
\hline \multicolumn{9}{|c|}{ 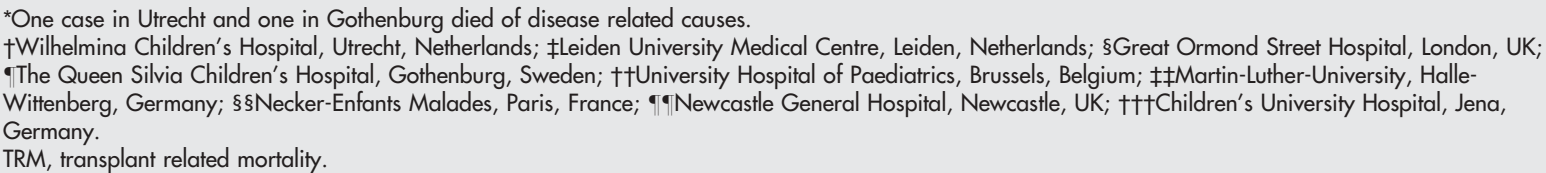 } \\
\hline
\end{tabular}

\section{General outcome}

Complete data on six core set criteria (baseline and at three month intervals) were available for 22 of the 34 patients $(65 \%)$. For the other 12 patients data on three to five core set criteria at three month intervals were available, always including the number of active joints. In these patients only three or more criteria were used to make an estimation of the improvement.

The general outcome of the patients is summarised in table 2. Eighteen of the 34 patients (53\%) with a follow up of 12 to 60 months (mean (SD), 29 (12) months) had complete drug-free remission. Seven of these patients had previously failed treatment with anti-TNF therapy. Five patients, who later achieved complete drug-free remission, had flare up of disease at three to six months post-ASCT; these events occurred either spontaneously while tapering the prednisone or following infection. Slower tapering of prednisone or low dose NSAID, and in one case intra-articular corticosteroids, was enough to control the flare up.

No response was noted in seven of the 34 patients $(21 \%)$. After an initial phase of improvement during immunoablation, these patients showed a complete relapse of the disease three to 17 months after ASCT, which was as severe as before and needed treatment with high doses of prednisone, methotrexate, anti-TNF therapy, cyclosporin A, and in one case even cyclophosphamide pulse therapy. In these patients the disease was as refractory to corticosteroids and other antirheumatic drugs as before ASCT. Two other patients who showed a complete relapse died 13 and 16 months after ASCT. The first patient developed a full blown relapse 13 months after ASCT and was treated with high dose prednisone, methotrexate, and cyclophosphamide pulse therapy. While waiting for HLA-matched allogenic bone marrow he developed an EBV infection and died of hepatic failure, being severely immunosuppressed. The second patient developed a primary varicella-zoster virus infection 13 months after transplantation. At that time she was being treated with anti-TNF therapy (etanercept) and methotrexate. Antirheumatic drugs were stopped and the patient was treated successfully with aciclovir. However, two months later she unexpectedly developed jaundice and died of liver failure of unknown aetiology.

Six of the 34 patients ( $18 \%$ ) showed a partial response. One of these had previously failed anti-TNF therapy. In these six patients, treatment with either low dose prednisone (two patients, 2.5 and $5 \mathrm{mg}$ prednisone daily) or other antirheumatic drugs was reinstituted at the time of the relapse, resulting in a subsequent improvement in the disease. Using the Giannini core set criteria for disease improvement (with modifications as above), these patients-who were refractory to these drugs before ASCT-now showed a $30-70 \%$ improvement in their disease. Figure 2 shows KaplanMeier curves with the proportion of surviving patients and the proportion of surviving patients free of either a partial or

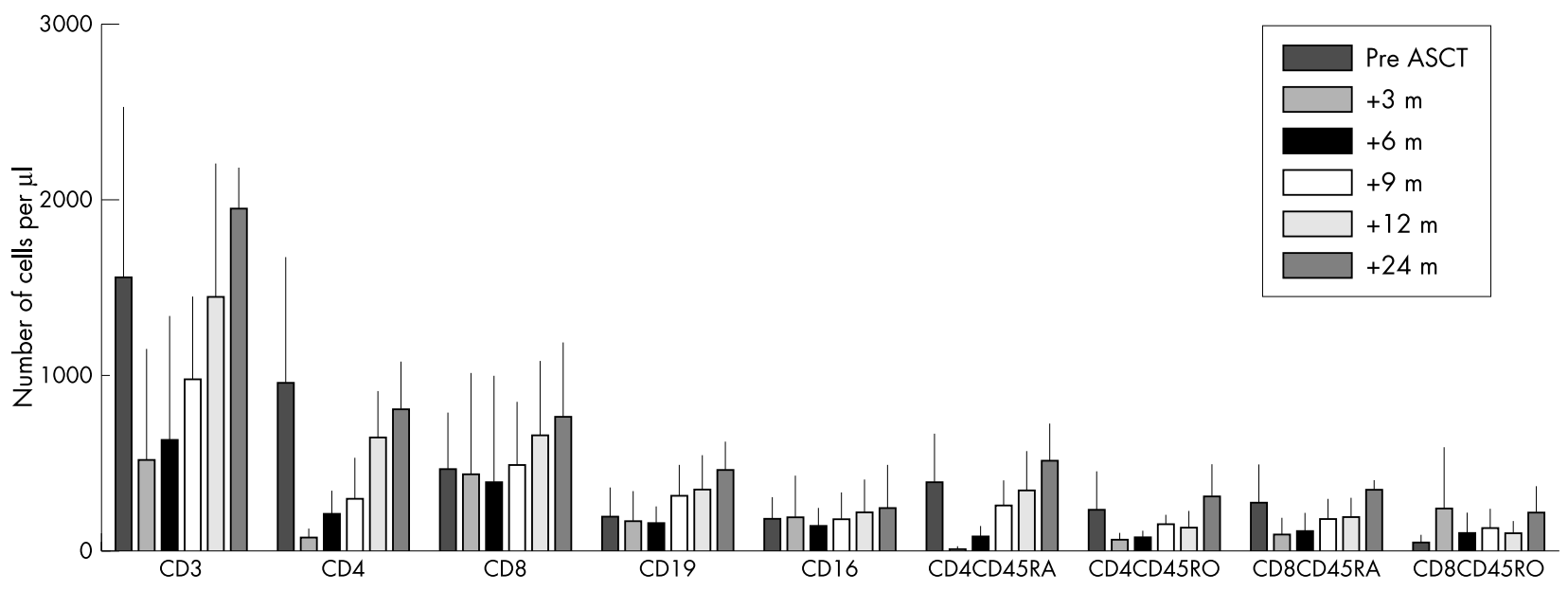

Figure 1 Reconstitution of lymphocyte subsets in 29 patients with juvenile idiopathic arthritis after autologous stem cell transplantation for 24 months. Error bars $=$ SEM. 


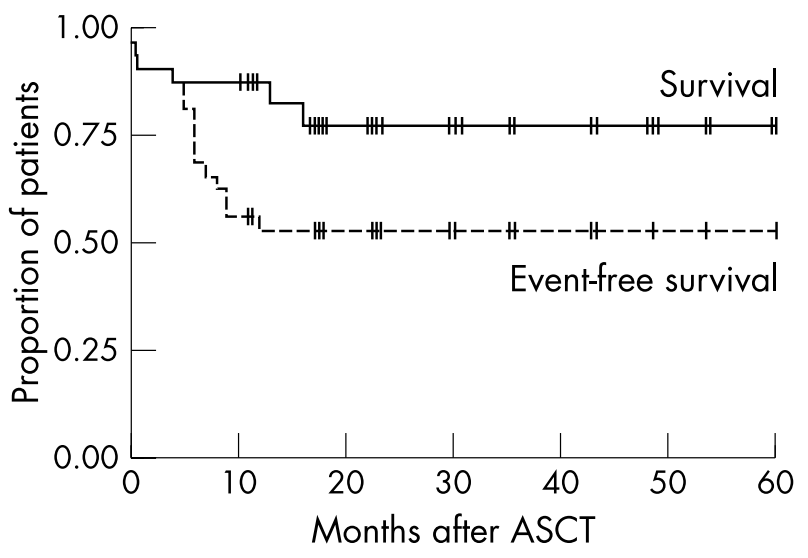

Figure 2 Kaplan-Meier curves showing the proportion of surviving patients and the proportion of event-free surviving patients. An event is defined as either a partial or complete recurrence of disease. Each bar mark represents the maximum follow up of a particular patient.

complete recurrence of the disease. Interestingly, all cases of mortality and all partial and complete relapses of disease occurred in the first 18 months after ASCT.

\section{Rheumatological follow up}

Figure 3 shows the available rheumatological follow up data for all patients. With the exception of EPM-ROM scores at time points 24,36 , and 48 months post-ASCT, there was a significant decrease in all core set criteria scores at time points $3,6,12,24,36$, and 48 months after ASCT $(p \leqslant 0.04)$. No correlation could be found between stem cell source, number of reinfused T cells, or engraftment and the clinical outcome. No statistically significant difference was seen in core set criteria scores obtained 12 and 24 months after ASCT between patients conditioned with protocol A (no TBI) and protocol B or C (with TBI).

\section{Transplant related complications and mortality}

All children developed chills, fever, and malaise during infusion of ATG. After ASCT, 24 of the 34 children (71\%) developed at least one infection, mainly during the aplastic period (table 3). During the aplastic period six children developed septicaemia; four blood cultures were positive for coagulase negative staphylococci and two for Streptococcus mitis. These cases all responded well to intravenous antibiotics. Ten patients developed a limited and one patient a generalised varicella-zoster virus eruption three to 18 months after ASCT, successfully treated with aciclovir. One patient had a primary cytomegalovirus (CMV) infection and six had CMV reactivation one to 12 months post-ASCT. One case each of localised atypical mycobacterial infection (six months after ASCT), Legionella pneumoniae infection (three months after ASCT), hepatitis A (18 months after ASCT), and herpes simplex virus (HSV) hepatitis (24 months after ASCT) were seen; all resolved completely.

Three patients with systemic JIA died shortly after ASCT of infectious complications. The first died of an infection associated haemophagocytic syndrome (IAHS), also called macrophage activation syndrome (MAS), induced by Epstein-Barr virus (EBV) four months after ASCT. At the time of the EBV infection, her JIA was in remission. The second fatal IAHS occurred 18 days after transplant, while the patient was still in aplasia. A third fatality, resembling IAHS, occurred 10 days after ASCT and was caused by a disseminated toxoplasmosis infection. ${ }^{35} 36$ Two further patients died 13 and 16 months after ASCT as described above.

\section{DISCUSSION}

Our study indicates that ASCT in severely ill patients with JIA induces complete drug-free remission in a substantial proportion of the patients (18 of 34 patients, 53\%), even after prolonged withdrawal of anti-rheumatic drugs. Also the patients who achieved a partial response (six of 34, 18\%) showed a remarkable improvement in most core set criteria, indicating a profound increase in general wellbeing. The limited improvement in paediatric EPM-ROM and CHAQ disability scores after ASCT shows that the erosive joint destruction which existed before ASCT was not reversed during the post-ASCT follow up in this study and might well turn out to be irreversible over a longer follow up. Yearly $x$ rays of the joints in a substantial proportion of the children who went into complete remission after ASCT (data not shown) suggested, however, that the progression of joint destruction had arrested after transplantation.

The high mortality in this study raises the issue of benefit versus risk of this procedure. Though mortality is seldom an immediate issue in most patients with JIA, various series published between 1981 and 1991 report a mortality of between $8 \%$ and $14 \%$ in children with systemic onset JIA (10\% of all cases). ${ }^{37-41}$ There is no doubt that with better treatment strategies the mortality has decreased in the last decade, but it is still estimated to be more than $2 \% .{ }^{6}$ The causes of death are quite evenly divided between disease related causes and treatment related causes. The high overall mortality in the group of children treated with ASCT therefore partly reflects the selection of the most severely ill patients. Infection associated haemophagocytic syndrome (IAHS) caused three of the five deaths in the present study. There is circumstantial evidence for a relation between systemic JIA and IAHS. ${ }^{42}{ }^{43}$ IAHS and systemic JIA share symptoms such as spiking fever, and untreated systemic JIA can progress to IAHS, with a high mortality. ${ }^{44} 45$ The occurrence of IAHS in systemic JIA after bone marrow transplantation may be caused by stringent $\mathrm{T}$ cell depletion, resulting in inadequate control of macrophage activation. ${ }^{42}$ In 1999 an international agreement was achieved on adaptation of the protocol, consisting of a less profound $\mathrm{T}$ cell depletion, control of systemic disease before transplantation, and a slow tapering of corticosteroids after ASCT. ${ }^{46}$ After adaptation of the protocol no further cases of IAHS have occurred.

The high frequency of infection in this study, including two deaths, illustrates the vulnerability of the patient group after ASCT. Whether the two patients dying of infection at 13 and 15 months after ASCT need to be considered as cases of transplant related or disease related mortality is questionable. Both patients were severely immunosuppressed as a result of high dose immunosuppressive drugs which were restarted because of a full blown relapse. Furthermore, though the immune system had fully reconstituted, it has been shown that after autografting severe immunodeficiency associated with persisting oligoclonality may continue for several years. ${ }^{33} 478$ Awareness that both factors amplify the immune suppression is important. Early recognition with immediate treatment of infections in this group of patients is even more important than before ASCT. Future protocols therefore need to include prophylactic administration of antiviral drugs and intravenous immunoglobulins until normal CD4+ T cell counts have returned, with frequent EBV monitoring by polymerase chain reaction. We believe that with the adaptations made to the protocol in 1999 to reduce MAS, the administration of prophylactics after ASCT, and an awareness of the risks of restarting immunosuppressive drugs shortly after ASCT, mortality can be reduced significantly.

Since the availability of anti-TNF therapy, failure of response to this treatment has been added as an inclusion criterion for future cases. The effects of etanercept in 
VAS-wellbeing

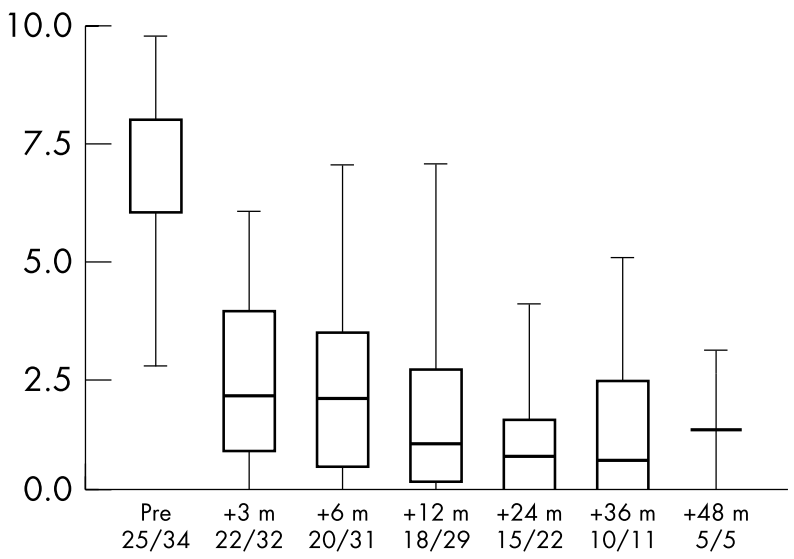

CHAQ-disability

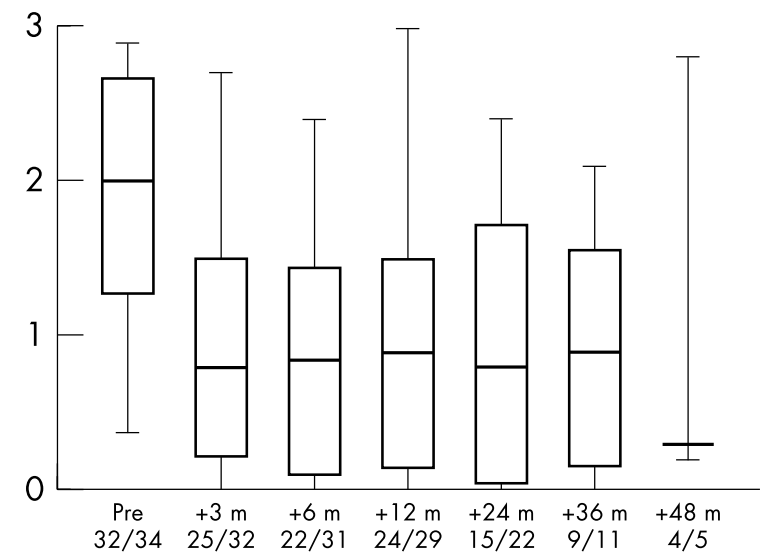

EPM-ROM

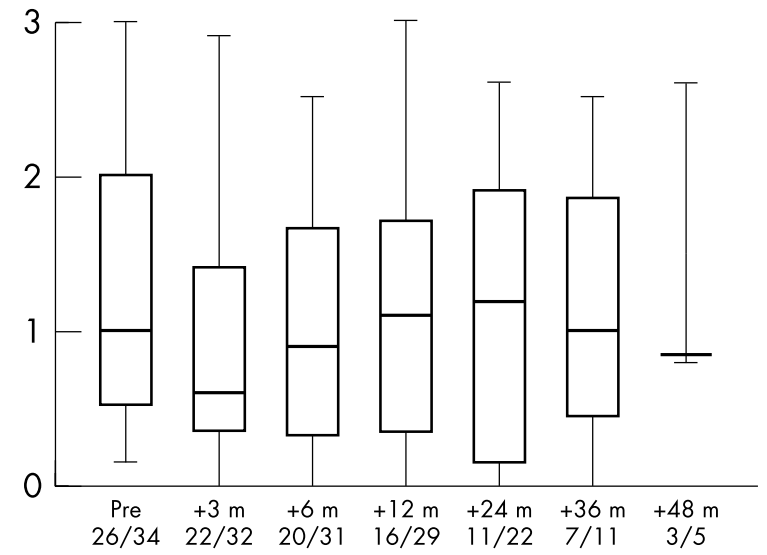

CHAQ-pain

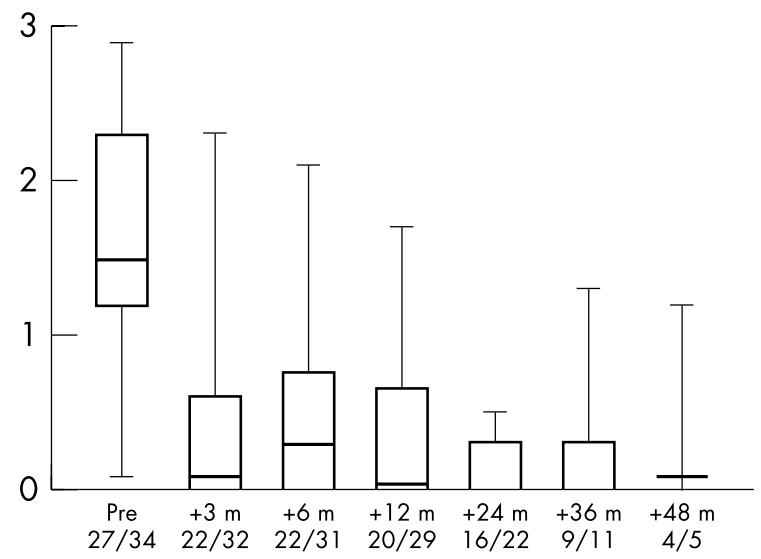

Active joint count

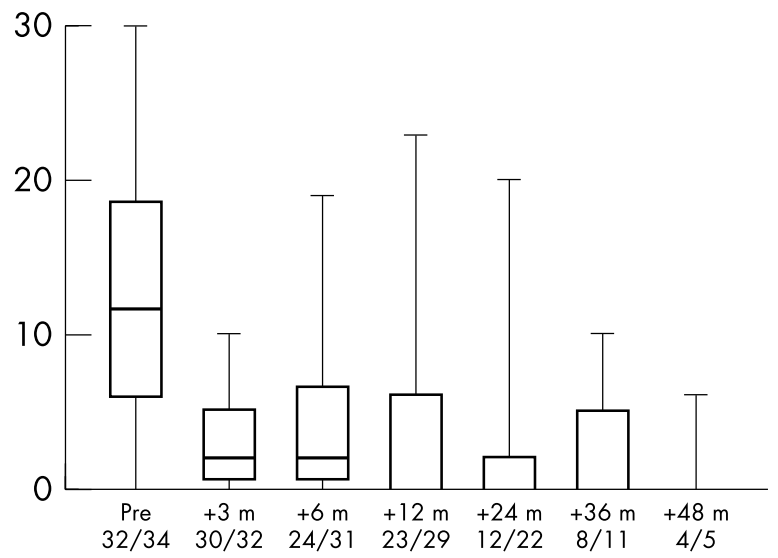

ESR

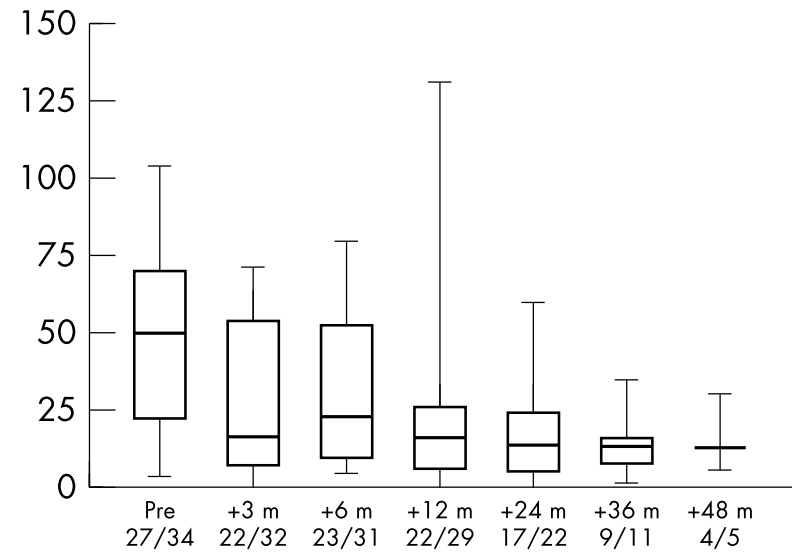

Figure 3 Rheumatological follow up before and at three monthly intervals after autologous stem cell transplantation. Error bars =SD. Numbers below the $x$ axis indicate ratios of the available data (number of data available/number of patients with indicated follow up). With the exception of EPM-ROM scores at time points 24,36 , and 48 months post-ASCT, all scores post-ASCT were significantly decreased compared with baseline (Wilcoxon signedrank test; all p values $\leqslant 0.04$ ). Top left: physician's global assessment of overall wellbeing (visual analogue scale, range 0-10); top right: parent/ patient assessment of pain (VAS, range 0-3); middle left: functional disability (child health assessment questionnaire (CHAQ), range 0-3); middle right: number of active joints (0-54); bottom left, number of joints with limited range of motion (paediatric EPM-ROM, range 0-3); bottom right, erythrocyte sedimentation rate $(E S R, \mathrm{~mm} / \mathrm{h})$.

polyarticular JIA are impressive, with a response rate up to $80 \%$ of methotrexate resistant patients with polyarticular JIA. ${ }^{9}$ So far no formal study has been undertaken on children with systemic JIA, but first experiences with anti-TNF therapy in patients with persistent systemic features have shown several treatment failures. ${ }^{112}$ Furthermore, the potential for severe adverse events with anti-TNF agents serves as an unfortunate limitation to this treatment. ${ }^{49-51}$ 


\begin{tabular}{|c|c|c|c|c|c|}
\hline Case & Infection & Time $^{*}$ & Case & Infection & Time $^{*}$ \\
\hline 1 & VZV, skin & $<3 \mathrm{~m}$ & 17 & Streptococcus mitis, blood & $<3 \mathrm{~m}$ \\
\hline 2 & Mycobacterium szulgai, eye & $6 \mathrm{~m}$ & & CMV reactivation & $<3 \mathrm{~m}$ \\
\hline \multirow[t]{2}{*}{3} & Xanthomonas maltophilia, stool & $<3 \mathrm{~m}$ & & VZV, skin & $12 \mathrm{~m}$ \\
\hline & HSV, hepatitis & $24 \mathrm{~m}$ & 18 & HSV type 1, throat & $<3 \mathrm{~m}$ \\
\hline \multirow[t]{2}{*}{4} & EBV, disseminated $\dagger$ & $12 \mathrm{~m}$ & 19 & Streptococcus mitis, blood & $<3 \mathrm{~m}$ \\
\hline & Streptococcus viridans, blood & $<3 \mathrm{~m}$ & & Generalised VZV & $<3 \mathrm{~m}$ \\
\hline 5 & VZV, skin & $<3 \mathrm{~m}$ & & Primary CMV & $<3 \mathrm{~m}$ \\
\hline \multirow[t]{2}{*}{6} & VZV, skin & $6 \mathrm{~m}$ & & Candida oesophagitis & $<3 \mathrm{~m}$ \\
\hline & Hepatitis A & $18 \mathrm{~m}$ & 20 & None & \\
\hline \multirow[t]{2}{*}{7} & Streptococcus, blood & $<3 \mathrm{~m}$ & 21 & VZV, skin $†$ & $12 \mathrm{~m}$ \\
\hline & VZV, skin & $18 \mathrm{~m}$ & 22 & None & \\
\hline \multirow[t]{3}{*}{8} & CMV reactivation & $4 \mathrm{~m}$ & 23 & Cryptosporidium, stool & $<3 \mathrm{~m}$ \\
\hline & EBV $(\dagger, M A S)$ & $4 \mathrm{~m}$ & 24 & None & \\
\hline & Candida oesophagitis & $<3 \mathrm{~m}$ & 25 & Candidal oesophagitis & $<3 \mathrm{~m}$ \\
\hline \multirow[t]{2}{*}{9} & CNS, blood & $<3 \mathrm{~m}$ & 26 & Toxoplasmosis, generalised ( + , MAS) & $<3 \mathrm{~m}$ \\
\hline & VZV, skin & $9 \mathrm{~m}$ & 27 & None & \\
\hline 10 & None & & 28 & Parainfluenza, blood & $<3 \mathrm{~m}$ \\
\hline \multirow[t]{3}{*}{11} & $H$ influenzae, blood & $<3 \mathrm{~m}$ & & CMV reactivation, blood & $<3 \mathrm{~m}$ \\
\hline & CNS, blood & $<3 \mathrm{~m}$ & 29 & Legionella pneumonia & $<3 \mathrm{~m}$ \\
\hline & VZV, skin & $9 \mathrm{~m}$ & & $C M V$ reactivation & $<3 \mathrm{~m}$ \\
\hline 12 & None & & 30 & CNS, blood & $<3 \mathrm{~m}$ \\
\hline \multirow{2}{*}{13} & VZV skin & $<3 \mathrm{~m}$ & & CMV reactivation, blood & $<3 \mathrm{~m}$ \\
\hline & CMV reactivation & $<3 \mathrm{~m}$ & & HSV, stomatitis & $<3 \mathrm{~m}$ \\
\hline 14 & None & & & Parainfluenza, blood & $<3 \mathrm{~m}$ \\
\hline \multirow[t]{2}{*}{15} & CNS, blood & $<3 \mathrm{~m}$ & 31 & CNS, blood & $<3 \mathrm{~m}$ \\
\hline & Adenovirus type 3 , faeces $\dagger$ & $<3 \mathrm{~m}$ & 32 & None & \\
\hline \multirow[t]{2}{*}{16} & HSV type 1, throat & $12 \mathrm{~m}$ & 33 & None & \\
\hline & Influenza A, nose & $<3 \mathrm{~m}$ & 34 & $\uparrow$ EBV genome copies & $<3 \mathrm{~m}$ \\
\hline
\end{tabular}

${ }^{*}$ Time point after autologous stem cell transplantation.

tDeath.

CMV, cytomegalovirus; CNS, coagulase negative staphylococcus; EBV, Epstein-Barr virus; HSV, herpes simplex virus; MAS, macrophage activation syndrome; VZV, varicella-zoster virus.

Among the 34 children in this study were eight with systemic JIA who had previously failed treatment with anti-TNF therapy; all eight responded extremely well to ASCT, confirming the possible role of this procedure in patients with severe disease.

The mechanism underlying the occurrence of complete remission after ASCT seems obvious. The rational of the treatment is eradication of the autoreactive lymphocytes and memory cells by a lymphoablative conditioning regimen, and subsequent rescue with $\mathrm{T}$ cell depleted autologous bone marrow. Regeneration of the $\mathrm{T}$ cell population occurs in the thymus by a process of proliferation and tolerisation to self, resulting in a "reset" immune system. Though it is generally thought that the recurrence of disease post-ASCT either reflects pathogenic cells in the stem cell graft or those remaining in the host, evidence is mounting that further depletion of $\mathrm{T}$ cells is not the answer to improving the outcome. In our study no correlation could be found between the number of reinfused T cells and the clinical outcome. This finding is consistent with a recent study by Moore et al showing similar outcomes in severe rheumatoid patients undergoing haemopoietic stem cell transplantation with unmanipulated cells and those receiving CD34 selected cells. $^{52}$ Furthermore, five patients in our study showed a

\begin{tabular}{|c|c|c|c|c|c|c|}
\hline Protocol & Conditioning & TCD & $\begin{array}{l}\text { Follow up } \\
\text { (months) }\end{array}$ & Inclusion criteria & Exclusion criteria & Supportive care \\
\hline $\bar{A}$ & $\begin{array}{l}\text { Cy, ATG, TBI } \\
\text { (low dose, } 4 \text { Gy) }\end{array}$ & $\mathrm{CD} 2 / 3$ or $\mathrm{CD} 34$ & 60 & $\begin{array}{l}\text { Drug resistant, } \\
\text { including anti-TNF }\end{array}$ & $\begin{array}{l}\text { Cardiorespiratory insufficiency, } \\
\text { chronic infections, active } \\
\text { systemic disease at time of } \\
\text { ASCT, end stage disease, poor } \\
\text { compliance }\end{array}$ & $\begin{array}{l}\text { No specific rules for } \\
\text { IVIG or antimicrobial } \\
\text { prophylaxis }\end{array}$ \\
\hline $\begin{array}{l}\mathrm{B} \\
\mathrm{C}\end{array}$ & $\begin{array}{l}\text { Cy, ATG } \\
\text { Cy, Flu, ATG }\end{array}$ & $\begin{array}{l}\text { CD34 } \\
\text { VCR or CD34 }\end{array}$ & $\begin{array}{l}42 \\
24\end{array}$ & & & \\
\hline $\begin{array}{l}\text { Proposed new } \\
\text { protocol }\end{array}$ & $\begin{array}{l}\text { Cy }(50 \mathrm{mg} / \mathrm{kg} / \mathrm{d} \text { at } \\
\text { day }-4 \mathrm{and}-1) \\
\text { ATG } 5 \mathrm{mg} / \mathrm{kg} / \mathrm{d} \text { at } \\
\text { day }-8 \text { to day }-5) \\
\text { Reinfusion of stem cells } \\
\text { at day } 0\end{array}$ & $\begin{array}{l}\text { CD34 selection } \\
\text { CD34>1 }>10^{6} / \mathrm{kg} \\
\text { and add back CD3 } \\
1 \times 10^{5} / \mathrm{kg}\end{array}$ & & Same as above & Same as above & $\begin{array}{l}\text { Isolation during aplastic } \\
\text { period } \\
\text { IVIG }(0.4 \mathrm{mg} / \mathrm{kg} \times 3 \\
\text { weeks) until CD3 count } \\
>500 / \mu \text { I } \\
\text { Pentamidine (PCP } \\
\text { prophylaxis, avoid } \\
\text { cotrimoxazol) }\end{array}$ \\
\hline $\begin{array}{l}\text { ASCT, autologo } \\
\text { monoclonal ant } \\
\text { intravenous imn } \\
\text { T cell depletion }\end{array}$ & $\begin{array}{l}\text { stem cell transplantatior } \\
\text { dies to CD2 or CD3 po } \\
\text { oglobulin; PCP, Pneumc } \\
\text { gg vincristine. }\end{array}$ & $\begin{array}{l}\text { G, anti-thymocy } \\
\text { lymphocytes; CL } \\
\text { s carinii pneumo }\end{array}$ & $\begin{array}{l}\text { bbit im } \\
\text { positiv } \\
\text { TBI, tot }\end{array}$ & $\begin{array}{l}\text { obulin (SangSta } \\
\text { ion of CD34+ st } \\
\text { irradiation; TC }\end{array}$ & $\begin{array}{l}\text { Fremont, California, USA); CD2 } \\
n \text { cells; Cy, cyclophosphamide; } \\
\text { T cell depletion; TNF, tumour }\end{array}$ & $\begin{array}{l}\text {, negative selection by } \\
\text {, fludarabin; IVIG, } \\
\text { rosis factor; VCR, ex vivo }\end{array}$ \\
\hline
\end{tabular}


benign, transient, oligoarticular synovitis before achieving complete remission, suggesting that some autoimmune $\mathrm{T}$ cells are still present after ASCT. The self limiting character of the synovitis favours the concept that ASCT not only resets autoimmune $\mathrm{T}$ cells, but also restores the regulation of these cells. $^{53}$

The above issue raises the question of whether $\mathrm{T}$ cell depletion of the marrow is crucial to the process of the transplant, or whether an intense but non-myeloablative regimen (with or without stem cell support) would be just as effective. Thus far, the conditioning agents used have been selected to maximise $\mathrm{T}$ cell eradication. Comparison of various conditioning regimens in animal models indicates that combination conditioning with high dose cyclophosphamide and low dose TBI is optimal. ${ }^{54}$ The use of TBI in children remains, however, controversial because of concerns about long term safety. Though the limited number of patients does not allow us to draw definitive conclusions, our present study suggests that children not given TBI have equally good outcome as those treated with irradiation. Given the obvious concerns over the use of TBI we propose to eliminate it from future conditioning regimens. Table 4 shows a proposed new protocol. A good controlled, prospective study is now needed to investigate the effectiveness of the new protocol.

\section{Conclusions}

Autologous stem cell transplantation in severely ill patients with JIA induces drug-free remission of the disease and profound improvement in general wellbeing in a substantial proportion of patients. However, the procedure carries a significant mortality risk, making it necessary to weigh carefully the morbidity and mortality risks of the prolonged immunosuppression of "conventional" treatment against those of the short but intense immunosuppression of ASCT.

\section{ACKNOWLEDGEMENTS}

U Neudorf, T Fiselier, and $M$ van Santen, paediatric rheumatologists, are acknowledged for patient referral. The clinical studies in the Netherlands were supported in part by a grant from the Dutch League against Rheumatism and the Dutch Organisation for Scientific Research (NWO).

\section{Authors' affiliations}

I M de Kleer, J van der Net, W Kuis, N M Wulffraat, Wilhelmina Children's Hospital of the University Medical Centre Utrecht, Utrecht, Netherlands

D M C Brinkman, $R$ ten Cate, M A J van Rossum, Leiden University Medical Centre, Leiden, Netherlands

L R Wedderburn, Institute of Child Health and Great Ormond Street Hospital, London WCl, UK

A Ferster, University Hospital of Paediatrics, Brussels, Belgium G Horneff, Centre of Paediatrics, Martin-Luther-University, HalleWittenberg, Germany

J Oppermann, Department of Rheumatology, Carl-Thiem Hospital, Cottbus, Germany

F Zintl, Department of Haematology/Oncology, Children's University Hospital, Jena, Germany

H Foster, M Abinun, Department of Child Health and Rheumatology, Newcastle Hospitals NHS Trust, Newcastle Upon Tyne, UK

P Quartier, A M Prieur, Unité d'Immunologie-Hématologie et Rhumatologie Pédiatriques, Hôpital Necker- Enfants Malades, Paris, France

A Fasth, Department of Paediatrics, Göteborg University and the Queen Silvia Children's Hospital, Gothenburg, Sweden

I M de Kleer and D M C Brinkman contributed equally to this work.

\section{REFERENCES}

1 Woo P, Wedderburn LR. Juvenile chronic arthritis. Lancet 1998;351:969-73.

2 Cassidy JT, Petty RE. In: Cassidy JT, Petty RE, eds. Textbook of pediatric rheumatology, 4th ed. Philadelphia: WB Saunders, 2002:218-321.
3 Wallace CA, Levinson JE. Juvenile rheumatoid arthritis: outcome and treatment for the 1990s. Rheum Dis Clin North Am 1991;17:891-905.

4 Gare BA, Fasth A. The natural history of juvenile chronic arthritis: a population based cohort study. I. Onset and disease process. J Rheumatol 1995;22:295-307.

5 Gare BA, Fasth A. The natural history of juvenile chronic arthritis: a population based cohort study. II. Outcome. J Rheumatol 1995;22:308-19.

6 Petty RE. Prognosis in children with rheumatic diseases: justification for consideration of new therapies. Rheumatology (Oxford) 1999;38:739-42.

7 David J, Vouyiouka O, Ansell BM, Hall A, Woo P. Amyloidosis in juvenile chronic arthritis: a morbidity and mortality study. Clin Exp Rheumatol 1993; 11:85-90.

8 French AR, Mason T, Nelson AM, O'Fallon WM, Gabriel SE. Increased mortality in adults with a history of juvenile rheumatoid arthritis: a populationbased study. Arthritis Rheum 2001;44:523-7.

9 Lovell DJ, Giannini EH, Reiff A, Cawkwell GD, Silverman ED, Nocton JJ, et al. Etanercept in children with polyarticular juvenile rheumatoid arthritis. Pediatric Rheumatology Collaborative Study Group. N Engl J Med 2000;342:763-9.

10 Quartier P, Taupin P, Bourdeaut F, Lemelle I, Pillet P, Bost M, et al. Efficacy of etanercept for the treatment of juvenile idiopathic arthritis according to the onset type. Arthritis Rheum 2003;48:1093-101.

11 Takei S, Groh D, Bernstein B, Shaham B, Gallagher K, Reiff A. Safety and efficacy of high dose etanercept in treatment of juvenile rheumatoid arthritis. J Rheumatol 2001;28:1677-80.

12 Kimura Y, Fieldston E, Devries-Vandervlugt B, Li S, Imundo L. High dose, alternate day corticosteroids for systemic onset juvenile rheumatoid arthritis. J Rheumatol 2000;27:2018-24.

13 Joske DJ, Ma DT, Langlands DR, Owen ET. Autologous bone-marrow transplantation for rheumatoid arthritis. Lancet 1997;350:337-8.

14 Traynor AE, Barr WG, Rosa RM, Rodriguez J, Oyama Y, Baker S, et al. Hematopoietic stem cell transplantation for severe and refractory lupus. Analysis after five years and fifteen patients. Arthritis Rheum 2002;46:2917-23.

15 Fassas A. Intense immunosuppression and autologous hematopoietic stem cell transplantation for multiple sclerosis. Haematologica 2003;88:244-5.

16 Tyndall A, Black C, Finke J, Winkler J, Mertlesmann R, Peter $\mathrm{HH}$, et al. Treatment of systemic sclerosis with autologous haemopoietic stem cell transplantation. Lancet 1997;349:254.

17 Passweg J, Gratwohl A, Tyndall A. Hematopoietic stem cell transplantation for autoimmune disorders. Curr Opin Hematol 1999;6:400-5.

18 Wulffraat NM, Kuis W, Petty R. Addendum: proposed guidelines for autologous stem cell transplantation in juvenile chronic arthritis. Paediatric Rheumatology Workshop. Rheumatology (Oxford) 1999;38:777-8

19 Tyndall A, Gratwohl A. Blood and marrow stem cell transplants in autoimmune disease: a consensus report written on behalf of the European League against Rheumatism (EULAR) and the European Group for Blood and Marrow Transplantation (EBMT). Bone Marrow Transplant 1997; 19:643-5.

20 Wulffraat N, van Royen A, Bierings M, Vossen J, Kuis W. Autologous haemopoietic stem-cell transplantation in four patients with refractory juvenile chronic arthritis. Lancet 1999:353:550-3.

21 Wulffraat NM, Sanders LA, Kuis W. Autologous hemopoietic stem-cell transplantation for children with refractory autoimmune disease. Curr Rheumatol Rep 2000;2:316-23.

22 Nakagawa R, Kawano Y, Yoshimura E, Suzuya H, Watanabe T, Kanamaru S, et al. Intense immunosuppression followed by purified blood CD34+ cell autografting in a patient with refractory juvenile rheumatoid arthritis. Bone Marrow Transplant 2001;27:333-6.

23 Lepore L, Kiren V. Autologous bone marrow transplantation versus alternative drugs in pediatric rheumatic diseases. Haematologica 2000;85:89-92.

24 Wulffraat NM, Brinkman D, Ferster A, Opperman J, ten Cate R, Wedderburn $L$, et al. Long-term follow-up of autologous stem cell transplantation for refractory juvenile idiopathic arthritis. Bone Marrow Transplant 2003;32(suppl 1):S61-4.

25 Giannini EH, Ruperto N, Ravelli A, Lovell DJ, Felson DT, Martini A. Preliminary definition of improvement in juvenile arthritis. Arthritis Rheum 1997; 40: 1202-9

26 Ruperto N, Ravelli A, Falcini F, Lepore L, De Sanctis R, Zulian F, et al. Performance of the preliminary definition of improvement in juvenile chronic arthritis patients treated with methotrexate. Italian Pediatric Rheumatology Study Group. Ann Rheum Dis 1998;57:38-41.

27 Singh G, Athreya BH, Fries JF, Goldsmith DP. Measurement of health status in children with juvenile rheumatoid arthritis. Arthritis Rheum 1994;37:1761-9.

28 Fuchs HA, Pincus T. Reduced joint counts in controlled clinical trials in rheumatoid arthritis. Arthritis Rheum 1994:37:470-5.

29 Len C, Ferraz MB, Goldenberg J, Oliveira LM, Araujo PP, Quaresma MR, et al. Pediatric Escola Paulista de Medicina Range of Motion Scale: a reduced joint count scale for general use in juvenile rheumatoid arthritis. J Rheumatol 1999:26:909-13

30 Pinals RS, Masi AT, Larsen RA. Preliminary criteria for clinical remission in rheumatoid arthritis. Arthritis Rheum 1981;24:1308-15.

31 Slaper-Cortenbach IC, Wiingaarden-du Bois MJ, Vries-van Rossen A, Borst HP, van der $L H$, van Heugten HG, et al. The depletion of $T$ cells from haematopoietic stem cell transplants. Rheumatology (Oxford) 1999;38:751-4.

32 Comans-Bitter WM, de Groot R, van den BR, Neijens HJ, Hop WC, Groeneveld K, et al. Immunophenotyping of blood lymphocytes in childhood. Reference values for lymphocyte subpopulations. J Pediatr 1997; 130:388-93.

33 Burt RK, Traynor AE, Pope R, Schroeder J, Cohen B, Karlin KH, et al. Treatment of autoimmune disease by intense immunosuppressive conditioning and autologous hematopoietic stem cell transplantation. Blood 1998:92:3505-14. 
34 Guillaume T, Rubinstein DB, Symann M. Immune reconstitution and immunotherapy after autologous hematopoietic stem cell transplantation. Blood 1998;92:1471-90.

35 ten Cate R, Brinkman DM, van Rossum MA, Lankester AC, Bredius RG Egeler MR, et al. Macrophage activation syndrome after autologous stem cell transplantation for systemic juvenile idiopathic arthritis. Eur J Pediatr 2002;161:686-6.

36 Quartier P, Prieur AM, Fischer A. Haemopoietic stem-cell transplantation for juvenile chronic arthritis. Lancet 1999;353:1885-6.

37 Stoeber E. Prognosis in juvenile chronic arthritis. Follow-up of 433 chronic rheumatic children. Eur J Pediatr 1981;135:225-8.

38 Salliere D, Segond P, Bisson M, Massias P. [Long follow-up study of juvenile chronic arthritis (author's translation)]. Sem Hop 1981;57:1155-60.

39 Hafner R, Truckenbrodt $\mathrm{H}$. [Course and prognosis of systemic juvenile chronic arthritis - retrospective study of 187 patients]. Klin Padiatr 1986;198:401-7.

40 Cabane J, Michon A, Ziza JM, Bourgeois P, Bletry O, Godeau P, et al. Comparison of long term evolution of adult onset and juvenile onset Still's disease, both followed up for more than 10 years. Ann Rheum Dis 1990;49:283-5.

41 Prieur AM. [Systemic forms of idiopathic juvenile arthritis: clinical course] Presse Med 2000;29:503-9.

42 Mouy R, Stephan JL, Pillet P, Haddad E, Hubert P, Prieur AM. Efficacy of cyclosporine $A$ in the treatment of macrophage activation syndrome in juvenile arthritis: report of five cases. J Pediatr 1996;129:750-4.

43 Stephan JL, Zeller J, Hubert P, Herbelin C, Dayer JM, Prieur AM. Macrophage activation syndrome and rheumatic disease in childhood: a report of four new cases. Clin Exp Rheumatol 1993;11:451-6.

44 Ravelli A. Macrophage activation syndrome. Curr Opin Rheumatol 2002; 14:548-52

45 Sawhney S, Woo P, Murray KJ. Macrophage activation syndrome: a potentially fatal complication of rheumatic disorders. Arch Dis Child 2001:85:421-6.

46 Wulffraat N. Autologous stem cell transplantation (ASCT) in refractory polyarticular and systemic JIA. Proceedings of the European League of Rheumatism (EULAR) meeting, Glasgow. Ann Rheum Dis 1999;58(S):25.
47 Wedderburn LR, Jeffery R, White H, Patel A, Varsani $H$, Linch D, et al. Autologous stem cell transplantation for paediatric-onset polyarteritis nodosa: changes in autoimmune phenotype in the context of reduced diversity of the Tand $\mathrm{B}$-cell repertoires, and evidence for reversion from the $\mathrm{CD} 45 \mathrm{RO}(+)$ to RA(+) phenotype. Rheumatology (Oxford) 2001;40:1299-307.

48 Tyndall A, Fassas A, Passweg J, Ruiz de Elvira C, Attal M, Brooks P, et al. Autologous haematopoietic stem cell transplants for autoimmune diseasefeasibility and transplant-related mortality. Autoimmune Disease and Lymphoma Working Parties of the European Group for Blood and Marrow Transplantation, the European League Against Rheumatism and the International Stem Cell Project for Autoimmune Disease. Bone Marrow Transplant 1999:24:729-34.

49 Gomez-Reino JJ, Carmona L, Valverde VR, Mola EM, Montero MD. Treatment of rheumatoid arthritis with tumor necrosis factor inhibitors may predispose to significant increase in tuberculosis risk: a multicenter active-surveillance report. Arthritis Rheum 2003:48:2122-7.

50 Ziakas PD, Giannouli S, Tzioufas AG, Voulgarelis M. Lymphoma development in a patient receiving anti-TNF therapy. Haematologica 2003:88:ECR25.

51 Kroesen S, Widmer AF, Tyndall A, Hasler P. Serious bacterial infections in patients with rheumatoid arthritis under anti-TNF-alpha therapy. Rheumatology (Oxford) 2003;42:617-21

52 Moore J, Brooks P, Milliken S, Biggs J, Ma D, Handel M, et al. A pilot randomized trial comparing $C D 34$-selected versus unmanipulated hemopoietic stem cell transplantation for severe, refractory rheumatoid arthritis. Arthritis Rheum 2002;46:2301-9.

53 de Kleer IM, Kamphuis SM, Rijkers GT, Scholtens L, Gordon G, De Jager W, et al. The spontaneous remission of juvenile idiopathic arthritis is characterized by CD30+ T cells directed to human heat-shock protein 60 capable of producing the regulatory cytokine interleukin-10. Arthritis Rheum 2003;48:2001-10.

54 van Bekkum DW. Effectiveness and risks of total body irradiation for conditioning in the treatment of autoimmune disease with autologous bone marrow transplantation. Rheumatology (Oxford) 1999;38:757-61. 